\title{
KEPEMIMPINAN KYAI DAN PERUBAHAN KONSEP PONDOK PESANTREN PADA PESANTREN TA MIRUL ISLAM SURAKARTA
}

\author{
Musta'an'), Muhammad Dian Rifai Sari²) \\ 1,2Universitas Sahid Surakarta \\ 1mustaan57@gmail.com \\ 2dianrifai344@gmail.com
}

\begin{abstract}
ABSTRAK
Penelitian ini bertujuan untuk menemukan, menganalisa serta menelaah secara mendalam kepemimpinan kyai untuk melakukan perubahan pondok pesantren dengan melihat konsep perubahan pondok pesantren Ta'mirul Islam Surakarta. Penelitian ini menggunakan pendekatan penelitian deskriptif kualitatif phenomenology. Pendekatan ini dipilih karena dalam penelitian ini peneliti akan mendiskripsian secara rinci serta mendalam mengenai gambaran kondisi yang sebenarnya terjadi di lapangan. Data kualitatif diperoleh dari hasil wawancara, observasi kelas dan dokumen. Sumber dan teknik triangulations digunakan untuk mendapatkan kepercayaan dari data ini. Selanjutnya, Flowchart Model yang diusulkan oleh Miles dan Huberman diterapkan dalam hasil study. Hasil penelitian, maka ditemukan bahwa: (1). Dalam penelitian ini peneliti menemukan konsep kepemimpinan kyai dalam melakukan perubahan di situs pondok pesantren Al-Muayyad dan Ta'mirul Islam Surakarta meliputi beberapa hal yaitu; Pembaharuan visi dan misi, perubahan kurikulum, Perubahan Isi/subtansi, perubahan metode pendidikan, perubahan kelembagaan dan perubahan tenaga pengajar/ustadz dan ustadzah. Temuan formal pada penelitian ini adalah Kyai dalam melakukan perubahan pada model pondok pesantren yang meliputi; changing structure (kelembagaan, kurikulum, subtansi), changing technology (perubahan metode pendidikan, sarana dan prasarana), changing people (visi-misi dan tenaga pendidikan).

Kata Kunci: Pesantren, perubahan, pendidikan, kepemimpinan, kyai
\end{abstract}

\begin{abstract}
This study aims to find, analyze and examine in depth the leadership of the cleric to make changes to the Islamic boarding school by looking at the concept of changing the Islamic Ta'mirul Islamic boarding school in Surakarta. This study uses a descriptive qualitative research approach to
\end{abstract}


phenomenology. This approach was chosen because in this study the researcher will describe in detail and in-depth the description of the actual conditions that occur in the field. Qualitative data were obtained from interviews, classroom observations, and documents. Sources and triangulation techniques are used to gain trust from this data. Next, the Flowchart Model proposed by Miles and Huberman was applied in the study results. The results of the study, it was found that: (1). In this study, researchers found the concept of Kyai leadership in making changes at the Al-Muayyad and Ta'mirul Islamic boarding school sites in Surakarta including several things namely; Renewal of vision and mission, changes in curriculum, changes in content/substance, changes in educational methods, changes in institutions and changes in teaching staff/clerics and clerics. Formal findings in this study are Kyai in making changes to the model boarding school which includes; changing structure (institutional, curriculum, substance), changing technology (changing educational methods, facilities, and infrastructure), changing people (vision-mission and education personnel).

Keywords: Islamic boarding, change, education, leadership, kyai.

\section{PENDAHULUAN}

Era globalisasi dewasa ini akan mempengaruhi perkembangan sosial budaya masyarakat muslim Indonesia. Hampir semua sendi kehidupan manusia mengalami perubahan yang sangat dahsyat. Perubahan ini dapat dilihat dari adanya perubahan pada berbagai macam institusi. Institusi sosial-kemasyarakatan, kenegaraan, keluarga dan keagamaan tidak luput dari perubahan (Basyit, 2017). Adapun institusi keagamaan yang dimaksud adalah lembaga pendidikan keagamaan (Pesantren) Sementara itu, term modern pada perkembangan globalisasi memiliki daya serap yang sangat ampuh, termasuk pada dunia pesantren. Namun ketika masuk dalam ranah globalisasi, pesantren memiliki banyak problem sehingga ada keharusan yang mesti dilakukan oleh lembaga pendidikan pesantren untuk melakukan modernisasi yang merupakan proses multi dimensional yang sangat kompleks (Syamsudin, 2017).

Dalam kaitannya dengan pendidikan, modernisasi dapat dilihat dari dua segi. Baik dari segi variabel modernisasi ataupun sebagai objek modernisasi. Dalam konteks ini, pendidikan secara umum masih dianggap terbelakang dalam berbagai hal, oleh karenanya sistem pendidikan yang ada harus diperbaharui/dimodernisasi, termasuk pendidikan Islam (Masrur, 2014). Modernisasi pendidikan Islam di Indonesia, yang berkaitan erat dengan pertumbuhan gagasan modernisasi Islam akan mempengaruhi dinamika keilmuan di lingkungan pesantren. Modernisasi sistem 
pendidikan pesantren dapat mengadopsi aspek-aspek tertentu dari sistem pendidikan modern, seperti: kurikulum, teknik dan metode pengajarannya. Dengan demikian, sebagai agen perubahan, apakah pemimpin akan turun lapangan untuk melihat kodisi riil santrinya, atau pemimpin hanya duduk dan menerima laporan serta menentukan kebijakkan adalah hal yang sangat menarik dalam dunia pondok pesantren (Badar, 2018). Oleh karena itu, Peran pemimpin sebagai agen perubahan tersebut yang akan menjadi fokus kajian penelitian ini.

Penelitian ini memiliki fokus pada pondok pesantren Ta'mirul Islam Surakarta. Peneliti bermaksud mendalami serta menganalisa kepemimpinan Kyai dalam melakukan perubahan pada pesantren tersebut. Pondok pesantren Ta'mirul Islam memiliki keunikan yang lain dibanding sekolah secara umum. Pondok yang dahulunya juga merupakan pondok pesantren tradisional kini telah menjadi pondok pesantren modern yang bisa bersaing dengan sekolah umum lainnya. Saat ini, Pondok pesantren Ta'mirul bekerja sama dengan lembaga University of Cambridge International Examinations (Alamer, 2009)(Finch, 2012). Pondok pesantren ini memiliki keunikan yang sama karena berawal dari pondok pesantren yang tradisional yang hanya fokus pada pengajaran ala pesantren lama dan sekarang telah melakukan perubahan yang sangat baik dengan peran dari kepemimpinan Kyai didalamnya. Oleh karena itu penulis tertarik untuk mendalami lebih mendalam dan bermaksud untuk melakukan penelitian yang berjudul "konsep perubahan yang dilakukan kyai di pondok pesantren Ta'mirul Islam Surakarta.

\section{METODE PENELITIAN}

Jenis penelitian ini adalah penelitian deskriptif analitik, dalam menganalisis Perubahan pondok pesantren dengan melihat konsep perubahan pondok pesantren Ta'mirul Islam Surakarta. Informan dalam penelitian ini adalah seluruh pimpinan dari pondok pesantren Ta'mirul Islam Surakarta dan jajarannya. Sedangkan, teknik pengambilan data dalam penelitian ini menggunakan wawancara, observasi dan dokumentasi. Data yang dikumpulkan dalam penelitian ini bersumber dari data primer yang diperoleh dengan menggunakan pendekatan kualitatif (Ahmadi, 2014).

\section{PEMBAHASAN}

$>$ |Musta'an \& Muhammad Dian Rifai Sari|

Perubahan Pondok Pesantren dengan Melihat Konsep Perubahan Pondok Pesantren Ta'mirul Islam Surakarta 
76 | Tarbawi : Jurnal Pendidikan Islam Vol. 17. No. 2. Juli - Desember 2020

\section{Pembaharuan Visi dan Misi}

Sebelum melangkah pada hal lainnya Kyai Abdul alim terlebih dahulu melakukan pembaharuan pada visi misi pesantren. Kyai abdul Alim paham betul akan pentingnya visi dan misi yang akan mempengaruhi perjalanan pesantren. Hal ini sangat relevan dengan pendapat Muhaimin yang menyatakan bahwa perubahan akan sukses jika telah dipenuhi komponen : visi, misi, skill, insentif, sumber daya, rencana karja.

Visi dan misi pondok pesantren Ta'mirul Islam adalah sebagai berikut ; Visi pondok pesantren Ta'mirul Islam yakni “mencetak kader ulama 'amilin penerus Rasulullah berbasis sanad dan menjadi perekat umat". Misi Pondok Pesantren Ta'mirul Islam adalah sebagai berikut; Tahqiqul 'ulum bissanad yang artinya semua ilmu yang diajarkan berdasarkan pada sanad. 2)Tazkiyatun nafs. Tazkiyatun nafs berasal dari dua buah kata yaitu Tazkiyatun dan An-nafs. Salahsatu arti Tazkiyatun yaitu membersihkan dan mensucikan. Sedangkan annafs artinya ruh atau jiwa. Jadi maksud dari tazkiyatul nafs yaitu upaya manusia untuk mensucikan jiwa dan dirinya, sehingga ia mempunyai sifat terpuji pada dirinya di dunia tentunya dan kelak di akhirat mendapatkan pahala dan balasan yang sesuai dengan perbuatannya. Tazkiyatul nafs dapat dilakukan dengan berbagai bentuk ibadah, seperti dzikurullah, mujahadah, khidmat, dan amal shalih.3) Da'wah Ilallah, harapan para pimpinan pondok agar para ustadz maupun santrinya mampu mengamalkan ilmunya ke masyarakat sekitar salah satunya dengan da'wah, agar para umat selalu berada di jalan Allah, "Fi Ayyi Ardhin Tatho', anta masulun 'an islamiha” dimanapun kamu menginjakkan kaki, maka kau bertanggung jawab atas keislaman (penduduknya) ulama.

Dengan adanya pembaharuan visi dan misi tersebut diharapkan akan tercipta santri-santri berkualitas yang mampu bersaing dikehidupan luar dengan memiliki akhlak dan keimanan yang kuat. Disamping visi dan misi pondok pesantren Ta'mirul Islam juga memiliki semboyan yang sangat khas yaitu "Iso ngaji lan ora kalah karo sekolah negeri" dengan jargon panca jiwa keikhlasan, kesadaran, kesederhanaan, keteladanan dan kasih sayang. Hal ini menunjukkan bahwa pernyataan Visi (vision statements) merupakan langkah pertama terpenting dalam agenda perubahan. Oleh karena itu visi harus mampu menjawab pertanyaan "what do we want to become?. Pernyataan visi cukup dengan kalimat tunggal misalnya Our vision is to take care of your vision. 


\section{Perubahan Kurikulum}

Secara sosiologis peran dan fungsi kyai sangat vital. la memiliki kedudukan yang tak terjangkau, terutama oleh kebanyakan orang awam. Kyai dengan segala kelebihannya, serta betapapun kecil lingkup kawasan pengaruhnya, masih diakui oleh masyarakat sebagai figur ideal karena adanya kedudukan kultural dan struktural yang tinggi.

Realitas ini memungkinkan kyai berkontribusi besar terhadap aneka problem keumatan. Peran kyai tidak hanya terbatas pada aspek spiritual, namun juga aspek kehidupan sosial yang lebih luas. Prinsip demikian koheren dengan argumentasi Geertz (1960) yang menunjukkan peran kyai tidak hanya sebagai seorang mediator hukum dan doktrin Islam, tetapi sebagai agen perubahan sosial (Social Change) dan perantara budaya (cultural broker). Ini berarti, kyai memiliki kemampuan menjelajah banyak ruang karena luasnya peran yang diembannya. Sejak Islam menjadi "agama resmi" orang Jawa, para penguasa harus berkompetisi dengan pembawa panji-panji Islam atau para kyai dalam bentuk hirarki kekuasaan (Hafidh, 2017).

Perubahan yang terjadi dalam organisasi termasuk salah satunya adalah pondok pesantren, perlu melalui tahapan-tahapan yang sesuai dengan kemampuan yang dimiliki pondok pesantren tersebut. Perubahan akan dapat diperoleh hasil yang optimal jika perubahan itu tumbuh dari dalam organisasi itu sendiri ketimbang dari faktor luar organisasi.

K.H. Abdul Alim adalah pengasuh pondok pesantren Pondok Pesantren Takmirul Islam. Beliau bertekad menjadikan Pesantren Ta'mirul islam yang paling unggul, untuk mempersembahkan kader-kader bangsa yang memiliki power maksimal dan ber-akhlakul karimah serta dapat terjangkau oleh seluruh lapisan masyarakat demi meraihi terwujudnya kesejahteraan dan tegaknya keadilan untuk seluruh bangsa Indonesia tanpa terkecuali”, demikian pernyataan pemangku pondok pesantren Takmirul Islam. Beliau berani melakukan terobosan besar untuk memodernisasi semua sistem pendidikan, kelembagaan dari pondok pesantren untuk mencapai cita-cita tersebut.

Langkah besar untuk mengembangkan dunia pendidikan itu benar-benar dilakukan $\mathrm{KH}$. Abdul Alim, begitulah orang biasa menyapanya. Boleh pendidikan.Kerja keras memeras otak, memunculkan ide dan gagasan unggul, semua beliau lakoni demi perbaikan dunia pendidikan, khususnya dunia 
78 | Tarbawi : Jurnal Pendidikan Islam Vol. 17. No. 2. Juli - Desember 2020

pesantren dan warga nahdliyin. Beliau membuat gebrakan dengan merubah semua susunan kurikulum yang sudah ada sejak dahulu, bukan karena tidak menghormati leluhur akan tetapi untuk merevitalisasi kurikulum pesantren yang sesuai dengan perubahan zaman.

Kurikulum Pondok pesantren Ta'mirul Islam yang dahulunya merupakan kurikulum tradisional yang semuanya tergantung pada pesantren maka saat ini kurikulum telah memadukan antara kurikulum tradisional dengan kurikulum yang berasal dari Gontor dan Cambridge University. Salah satu indikator pembaharuan Pesantren dalah keberadaan kurikulum formal dilingkungan pesntren. Pesantren dengan berbagai variasi dan motifnya, berani membuka diri dan menyelenggarakan pendidikan formal dalam bentuk madrasah atau sekolah. Sejak masa pertumbuhannya, pesantren memiliki peran dan fungsi yang signifikan. Peran dan fungsi tersebut, menurut Azyumardi Azra adalah: pertama, transmisi dan transfer ilmu-ilmu keislaman; kedua, pemeliharaan tradisi Islam; dan ketiga, reproduksi ulama.

Hampir serupa dengan rumusan Azyumardi, Ma'sum menyebutkan tiga fungsi utama pesantren, yaitu 1) fungsi religious (diniyyah), 2) fungsi sosial (ijtima'iyyah), dan fungsi pendidikan (tarbawiyyah) (Azra, 2017). Hal ini selaras dengan apa yang menjadi visi \& misi K.H. Abdul Alim yang ingin menjadikan Pesantren Ta'mirul Islam menjadi maju dalam segala bidang, menjadi sumber pengetahuan baik agama maupun umum serta dapat memberikan ketrampilan tambahan bagi santrinya guna menjadi bekal di dunia masyarakat. Hal itu beliau tuangkan dalam pembuatan kurikulum yang dipadukan antara kurikulum lama (tradisional) dengan kurikulum baru (Cambridge dan Gontor).

\section{Pembaharuan Isi/Subtansi}

Keteladanan adalah modal utama bagi seorang Kyai dalam membentuk sebuah fondasi pesantren yang kokoh. K.H. selalu memberikan contoh bagi semua civitas akademika pesantren sebelum menyusun Isi subtansi apa yang akan beliau berikan kepada para santrinya. Hal itu agar keberkahan dan kebaikan selalu berada pada pesantren yang beliau pimpin. Beliau tidak pernah mau mencalonkan diri menjadi pemimpin di pondok pesantren akan tetapi selalu dicalonkan karena kemampuannya yang luar biasa. Hal ini sesuai dengan teori tentang Kepemimpinan seharusnya tidak dicari apalagi diperebutkan, kecuali dalam kondisi tertentu untuk kemaslahatan yang lebih luas (Lubis, 2012). 
Rasulullah bersabda, yang artinya "Sungguh saya tidak akan memberikan kepemimpinan ini kepada orang yang mencarinya, karena sesungguhnya kepemimpinan itu adalah amanah dan akan membawa derita nanti pada hari kiamat".

Tepat pada tahun 1985, beliau mendirikan lembaga pendidikan Pondok Pesantren Takmirul Islam. Meski masih muda, keberadaan lembaga pendidikan Takmirul Islam tidak bisa dianggap remeh. Tak tanggung-tanggung, sebut saja seperti Institut Teknologi Surabaya (ITS), FK (Fakultas Kedokteran) Universitas Airlangga, Institut Teknologi Bandung (ITB), Institut Pertanian Bogor (IPB), Universitas Indonesia (UI). Semua perguruan tinggi elit Nasional tersebut tak luput dari hunian para lulusan Pondok Pesantren Tamirul Islam sebagai tempat menimba ilmu lanjutan. Selain di dalam negeri, universitas luar negeri pun tak luput dari sasaran para alumninya. Sebut saja, Al-Azhar Kairo, Mesir serta Maroko ini. Hal ini bisa terjadi karena K.H.Abdul Alim mau membuka diri untuk memberikan tidak hanya ilmu agama akan tetapi juga mau membuka diri untuk mengembangkan keilmuan yang lebih banyak lagi.

Secara kultural, pelestarian tradisi keilmuan dan keagamaan di pesantren sangat bergantung pada sistem nilai yang dipeganginya, seperti pengagungan terhadap ilmu, guru atau kyai yang hampir "tak berbatas". Sistem nilai dalam tradisi seperti ini dianggap sebagai sesuatu yang taken for granted, yakni sistem yang harus diterima apa adanya sebagai produk jadi dan terbantahkan, tidak memerlukan penambahan substanti, kecuali hanya diperjelas atau dirumuskan kembali. Seiring perjalanan waktu, secara progresif, banyak pesantren mulai yang telah melakukan pembaharuan dalam berbagai aspek pendidikan di dunia pesantren.

Pembaharuan aspek substansi dan metodologi dapat disederhanakan menjadi pembaharuan aspek kurikulum Meski sekarang Lembaga Pendidikan agama Islam tersebut sudah banyak menghantarkan siswa-siswanya sukses dalam pendidikan menengah. Perlu dipahami, bahwa pembaruan ini berjalan secara bertahap, serta tidaklah semudah yang dibayangka pada setiap waktu dan tempatnya Namun menurut Kyai Kharismatik tersebut tersebut bahwa perjuangan selama ini belumlah apa-apa. Selain memiliki standar pendidikan unggul, prestasi yang diraih santri-santri atau siswa/siswi Takmirul Islam cukup banyak, seperti lomba dan kejuaraan ilmiah, bahkan lembaga pendidikan yang dihuni mayoritas 
santri berbasis nahdliyin ini kerap mengirim siswanya menjadi duta pertukaran pelajar ke luar negeri.

Perhatian serius datang lansung dari Kementrian Agama dan Kementrian Pendidikan. Kedua lembaga kementrian tersebut menyematkan sebuah lencana yang sangat membanggakan kepada Takmirul Islam sebagai lembaga pendidikan "Best Practice". Maksudnya adalah sebagai lembaga yang benar-benar dapat merealisasikan pola pendidikan yang terbaik kepada masyarakat. Berangkat dari keluarga pas-pasan $\mathrm{KH}$. Abdul Alim pada waktu muda. Beliau sempat mengembara hingga membawanya ke pulau seberang timur tengah diantara Umul qurro' (mekkah) dan al-Azhar (mesir) yang akhirnya beliau memutuskan kembali ke tanah Jawa menuju Surakarta.

Surakarta merupakan tanah kelahirannya, di kota tersebut, Kyai progresif ini ingin menambah keilmuwan keagamaan. Beliau memiliki karakter berpikir keras dan berjiwa besar, meski pada masa mudanya berada pada ekonomi yang berjalan datar, alias naik turun; mirip kapal hendak tenggelam, tak pernah mengeluh sedikitpun, semboyan beliau "selama air kran masjid masih mengucur, saya pasti masih bisa hidup". Menumbuhkan ruh perjuangan demi izzul Islam wal muslimin bagi orang seperti $\mathrm{KH}$. Abdul Alim, terpaan kepedihan dimasa muda telah mencetak beliau sebagai seseorang yang memiliki cita-cita besar.

Hal ini merupakan modal besar bagi K.H. Abdul Alim dalam membangun sistem yang luar biasa rapinya, ini sesuai dengan teori perubahan yang menyatakan perubahan akan terjadi kalau ada sejumlah syarat tertentu yang menguntungkan. Namun dengan memiliki motivasi untuk berubah maka yang perlu dilakukan adalah fokus ke depan dengan cara membuang sikap pesimis, menciptakan kepatuhan, serta mengurangi ketidakpuasan (Fridiyanto, 2018).

\section{Pembaharuan Metode Pendidikan}

Perubahan arus budaya seharusnya bukan menjadi hambatan untuk mempertahankan tradisi kerifan Islam masa klasik, namun membuat nilai ajaran kitab Islam klasik menjadi sebuah kerangka dinamika yang lebih logis dan kekinian.Dan hal ini menjadi motivasi dalam dirinya untuk ditransver kepada para santrinya.Berbagai hambatan banyak ditemui oleh $\mathrm{KH}$. Abdul Alim, namun beliau menekankan "Ketika semua manusia tidak paham akan ilmu ibaratnya mereka menjadi seperti buih di lautan, maka ketahuilah hanya Allah yang akan menunjukkan bahwa dengan ilmulah Dia akan mengangkat derajat hamba-Nya". 
Kearifan beliau dalam bertindak serta berfikir cerdas diaktualisasikan dalam banyak hal. Beliau juga menyinggung banyak bagaimana manusia yang tidak berlandaskan pada nilai-nilai kearifan Islam telah terjerumus pada segmen negatif, seperti rusaknya moral anak bangsa. KH. Abdul Alim menegaskan bahwa: Adapun untuk merealisasikan cita-cita tersebut, $\mathrm{KH}$. Abdul Alim membuat sistem pesantren yang bertaraf internasional, dengan melibatkan beberapa negara, antara lain Yaman, Mesir, Maroko dan Amerika untuk bekerja sama dalam proses kegiatan pembelajaran, seperti bahasa asing.

Pondok Pesantren Ta'mirul Islam telah melakukan perubahan dalam metode pendidikannya yang semula menggunakan metode klasik seperti sorogan, wetonan menjadi sistem berjenjang, hafalan, musyawarah, studi banding dan sistem modern lainnya. Sarana dan prasarana dibuat senyaman mungking agar memberikan kemudahan kepada santri untuk belajar. Hal ini selaras dengan teori yang menyatakan respon pesantren terhadap modernisasi pendidikan Islam dan perubahan-perubahan sosial ekonomi yang berlangsung dalam masyarakat Indonesia sejak awal abad ini dapat dipetakan pada empat komponen: (a) Pembaharuan isi atau substansi pendidikan pesantren dengan memasukkan subyek umum dan vocational; (b) Pembaharuan metodologi, seperti sistem klasikal, penjenjangan; (c) Pembaharuan kelembagaan, seperti kepemimpinan pesantren, diversifikasi lembaga pendidikan; dan (d) Pembaharuan fungsi, dari fungsi kependidikan untuk juga mencakup fungsi sosial ekonomi yang lebih luas (AR, 2018).

Adanya pembaharuan metodologi adalah sarana bagi pesantren yang mau membuka diri agar pesantren tidak dianggap kuno dan tertinggal dengan lembaga pendidikan lainnya karena telah menyesuaikan diri dengan kemajuan zaman sehingga tidak ikut tergerus didalamnya.

Melihat pola berpikirnya tersebut, tersirat gambaran bahwa sebuah perubahan besar telah dilakukan demi terwujudkan cita-cita bangsa yang merdeka. Dalam hal ini perubahan yang diharapkan tentu saja perubahan ke arah yang lebih baik dan terukur dari waktu ke waktu. Sesungguhnya pesantren Takmirul Islam merupakan produk baru secara konsep menawarkan pendidikan akslerasi dan unggulan serta sekolah gratis di masyarakat. Secara mendalam, $\mathrm{KH}$.Abdul Alim membuat kerangka untuk memformatisasi metode pendidikan pola 
82 | Tarbawi : Jurnal Pendidikan Islam Vol. 17. No. 2. Juli - Desember 2020

lama yang dianggap gagal olehnya. Dan pada akhirnya, sistem baru ini sepenuhnya dapat diterima ditingkat regional, nasional bahkan internasional.

Pola yang ditawarkan adalah mencetak calon-calon doktor, mendirikan sekolah yang berintegritas tinggi agar cita-cita kemerdekaan benar-benar terealisasi Pesantren Takmirul Islam sebagai pesantren binaan $\mathrm{KH}$. Abdul Alim, merupakan lembaga pendidikan alternatif pendidikan masyarakat, mandiri, secara konsep dapat ditawarkan pada masyarakat yang sangat membutuhkan. Dari prestasi dan output siswanya, $\mathrm{KH}$. Abdul Alim ini telah merealisasi keseriusannya untuk menjadikan lembaganya sebagai pesantren yang berkualitas. Selain itu, kelahiran pesantren Takmirul Islam merupakan jawaban atas berbagai problematika kegagalan pendidikan di Indonesia, untuk itu Kyai Abdul Alim ingin mengembalikan hitțāh pendidikan sebagai wadah keilmuan.

Pada zaman yang modern ini, beberapa unsur tradisionalitas pesantren mulai mengalami perubahan. Salah satunya menyangkut metode pengajaran. Umumnya, pesantren mempertahankan sistem sorogan dan bandongan [Sunda: bandungan), yang memberi penekanan pada pembacaan teks "kitab kuning" [al-kutub al-safra] secara harfiah (letterlijk) dengan pengembangan secara metodologis yang"sangat terbatas". Prinsipnya, pembacaan ini "asal selesai dibaca" (khatam), baru kemudian diulang atau dilanjutkan ke kitab-kitab lainnya. Selebihnya, banyak pula pengulangan materi kitab yang sama dalam jenjang yang berbeda, yang dalam tradisi anekdot pesantren dikenal dengan istilah thaharah.

Metode pengajaran diatas menggambarkan suatu ketergantungan santri pada bacaan guru atau kyai-nya yang cukup tinggi. Secara praktis, hal ini berimplikasi pada pola pengajaran yang monolog, top down, berorientasi pada kyai (teacher oriented), serta terbatasnya pengembangan materi yang lebih luas. Faktor utama dari fenomena ini adalah pengagungan terhadap ilmu dan kyai yang sangat tinggi dari para santri. Selain itu, pola pengajaran seperti ini dipengaruhi pula oleh struktur sosial-intelektual pesantren yang sangat hirarkis (Jamaluddin, 2012). Terpengaruh oleh gerakan pembaharuan, beberapa pesantren mulai merubah metode pembelajarannya termasuk di pondok pesantren Ta'mirul Islam. Sistem klasikal mulai diterapkan pada pesantren ini. Sistem teacheroriented beralih ke student oriented. Bahkan juga diterapkan sistem berjenjang sistem sekolah formal, seminar dengan menggunakan media modern seperti LCD, 
laboratorium. Semua itu untuk pembaharuan agar ilmu-ilmu dapat berkembang tanpa meninggalkan tradisi lama.

Melakukan perubahan dari keadaan sebelumnya ke arah yang lebih baik merupakan keharusan yang harus dilakukan sejalan dengan perintah Allah SWT dalam Al-Qur'an yang terdapat dalam surah Ar-Ra'du ayat 11 yang Artinya: "Sesungguhnya Allah tidak akan mengubah nasib suatu kaum kecuali kaum itu sendiri yang mengubah apa apa yang pada diri mereka ".

Rumusan konsep yang berangkat dari pola modernisasi metode positif, sebagaimana yang telah dijelaskan, terasa lebih kompleks bila dibandingkan dengan konsep Kyai lainnya. Rumusan tersebut telah tercermin perpaduan antara semangat keagamaan dan pengembangan serta kepedulian terhadap nasib bangsa.Hal ini cukup beralasan sekali, karena beliau telah lahir dari perjuangan keras untuk mendapatkan pendidikan yang layak. KH.Takmirul Islam dengan Masyarakat Pendidikan merupakan investasi dan instrumen yang sangat berharga bagi masyarakat. Pendidikan yang dapat menjanjikan adalah pendidikan yang dapat mengantarkan perubahan yang sangat berarti bagi masyarakat tersebut.

Selanjutnya, perubahan model pembelajaran yang beraneka-ragam dalam mewujudkan urgensitasnya tidak dapat dilepas-pisahkan dengan tututan situasi dan kondisi masyarakat yang dimaksud țībaqahu lī muqtadal maqāmi Prosesi perkembangan pendidikan di tengah masyarakat ternyata sering kehilangan rūh al-tarbiyah-nya, sehingga usaha semangat untuk mengedepankan pendidikan terhadap masyarakat dibanding lainnya tidak jarang terabaikan. Problematika internal pendidikan masyarakat yang sangat konprehenship perlu mendapatkan perhatian dan solusi terbaik, lebih-lebih pada masyarakat yang belum dapat menikmati layaknya pendidikan formal (al-du’afā wa al-Mustad 'afinn).

Bertolak dari desakan di atas, $\mathrm{KH}$. Abdul Alim sebagai seorang muslim yang progresif dapat melahirkan eksplorasi intelektual dikalangan santri di pesantren Takmirul Islamuntuk bergerak meneropong dan merespon dinamika persaingan yang ketat dalam era modernisasi, di samping terdapat berbagai tantangan globalisasi informasi yang menggejala di masyarakat.

Berlandaskan filosofi kejujuran dan kecerdasan, KH. Abdul Alim menciptakan konsep intelektual dan pembinaan spiritual. Di samping itu, beliau juga mendirikan sekolah gratis dilingkungan masyarakat Surakarta, sebagai bukti 
84 | Tarbawi : Jurnal Pendidikan Islam Vol. 17. No. 2. Juli - Desember 2020

bahwa pendidikan adalah oleh masyarakat dan untuk masyarakat. Piranti ampuh menghadapi setting modernisasi yang terdapat sisi positif pula, oleh KH.Abdul Alim digunakan sebagai potensi untuk melumpuhkan bahwa pendidikan yang bermutu dan berkualitas tidak bisa dijangkau oleh masyarakat kecil.

\section{Pembaharuan Kelembagaan}

Mendirikan lembaga pendidikan sebagai wujud ikut andil dalam mewujudkan makna pengembangan pendidikan agama Islam Kepedulian terhadap perkembangan pendidikan inilah yang membawa perubahan potret pesantren di wilayah Surakarta. Langkah K.H. yang berani untuk mengadopsi nilai-nilai modernisasi melalui berbagai macam perpaduan materi baik agama maupun umum secara koperehensif maka layak jika beliau mendapat julukan tipologi muslim progresif.

Julukan ini disematkan, karena beliau selalu mengadakan inovasi baru dalam sistem pendidikan dan tidak pernah dalam kamus beliau terdapat pemikiran yang statis terhadap dunia pendidikan. Beliau adalah tipikal Kyai yang selalu memiliki motivasi tinggi dalam pembaharuan baik dri sistem kelembagaan, isi subtansi dan metode pengajaran. Hal ini sesuai dengan teori Motivasi: dalam teori ini perubahan akan terjadi kalau ada sejumlah syarat tertentu yang menguntungkan. Namun dengan memiliki motivasi untuk berubah maka yang perlu dilakukan adalah fokus ke depan dengan cara membuang sikap pesimis, menciptakan kepatuhan, serta mengurangi ketidakpuasan.

Perjalanan hidup Kyai Abdul Alim telah membentuk karakternya begitu kuat untuk mengantarkan kegerbang cita-cita mulia. Kyai Abdul Alim sebutan akrabnya, berusaha untuk menjembati bagaimana mengadopsi nilai modernisasi perspektif Islam. Menurut Azyumardi, perubahan kelembagaan pesantren semakin mendapatkan momentumnya dalam dua dasawarsa belakangan. Hal ini terkait dengan kebijakan Undang-Undang Sistem Pendidikan Nasional (UU Sisdiknas) tahun 1989 (kemudian diperbarui pada 2003).

Pesantren-pesantren yang mengelola madrasah mengalami perubahan signifikan. UU Sisdiknas ini memosisikan madrasah menjadi setara (equivalent) dengan sekolah umum. Bahkan, dalam kerangka UU Sisdiknas tersebut, madrasah menjadi 'sekolah umum' berciri Islam. Sebagai konsekuensinya, sejak pemberlakuan UU Sisdiknas, madrasah mesti memberlakukan kurikulum Diknas dengan suplemen kurikulum Departemen 
Agama untuk beberapa mata pelajaran agama. Dengan demikian, pemerintah semakin intensif untuk mengintegrasikan lembaga dan sistem pendidikan pesantren ke dalam sistem pendidikan nasional. Pada sisi lain, pesantren pada klasifikasi ini semakin intensif mengadopsi dan mengintegrasikan kurikulum yang ditetapkan pemerintah ke dalam kurikulum pesantren.

Secara akumulatif, modernisasi dan tranformasi sistem kelembagaan pesantren menyangkut beberapa variable. Pertama, modernisasi administratif, yakni modernisasi menuntut adanya diversifikasi dan diferensiasi sistem pendidikan, untuk mengakomodasi dan mengantisifasi berbagai kepentingan diferensiasi sosial, teknik,dan manajerial. Kedua, differensiasi struktural, yakni pembagian dan diversifikasi lembaga-lembaga pendidikan sesuai dengan fungsifungsi yang akan dimainkannya. Ketiga, ekspansi kapasitas kelembagaan. Hal ini selaras dengan pemikirran K.H.Abdul Alim yang terus meningkatkat kualitas lembaga pesantren.

Dahulu pondok pesantren Ta'mirul Islam yang merupakan pondok kecil dengan struktur serta administrasi yang ala kadarnya sekarang berubah menjadi lebih modern. Dengan adanya sistem madrasah, kelas berjenjang struktur oragnisasi yang kuat serta sarana dan prasarana yang memadai. Pemikiran beliau inilah yang akhirnya menggerakkan dinamika pengembangan pesantren yang diasuhnya, dimana sebelumnya dipandang sebelah mata oleh masyarakat. Namun seiring berjalannya waktu, karena banyak inovasi yang telah dilakukannya, maka pesantren ini berkembang pesat dan banyak diminati oleh kalangan menengah atas.

Perkembangan ini disambut baik oleh beberapa instansi seperti Dinas Kementrian Agama dan Kementrian Pendidikan.Kecerdasan dan kepiwaiannya dalam membuat sistem baru seperti program lembaga sekolah akslerasi, unggulan dan beasiswa lokal telah membuktikan bahwa beliau benar-benar sanggup mengimbangi derasnya arus negatif modernisasi.

\section{Pembaharuan Tenaga Pengajar}

Kyai/Ustadz/guru merupakan elemen yang paling esensial dari suatu pesantren. Mayoritas kyai di Jawa beranggapan bahwa sebuah pesantren dapat diibaratkan sebagai suatu kerajaan kecil di mana kyai merupakan sumber mutlak dari kekuasaan dan kewenangan (power and authority) dalam kehidupan dan lingkungan pesantren. Meskipun kyai di Jawa tinggal di pedesaan, mereka 
merupakan bagian dari kelompok elite dalam struktur sosial, politik dan ekonomi masyarakat Jawa.

Para kyai/ustadz/guru yang memimpin pesantren besar telah berhasil memperluas pengaruh mereka di wilayah negara, hasilnya mereka banyak yang diterima di elit nasional. Sejak Indonesia merdeka banyak di antara mereka yang diangkat menjadi menteri, anggota parlemen, duta besar dan pejabat-pejabat tinggi pemerintahan. Tingkat perkembangan suatu pondok pesantren sangat tergantung kemampuan kyainya tersebut. Banyak pondok pesantren mengalami kemunduran bahkan ada yang tidak laku karena beberapa faktor dari kyainya tersebut, misalnya karena sang kyai meninggal dunia yang diteruskan keturunannya yang dianggap tidak cakap, atau sang kyai meninggal dunia tidak memiliki keturunan untuk meneruskan pondok pesantren yang dipimpinnya tersebut. Proses kelangsungan hidup dari pondok pesantren bergantung pada kemampuan dalam mempersiapkan para generasi kyai. Generasi penerusnyapun merupakan generasi yang mempunyai kapabilitas cukup tinggi minimal sepadan dengan kapabilitas sang kyai sebelumnya.

Selaras dengan tingkat perkembangan globalisasi, baik perkembangan sosial, perkembangan politik, perkembangan budaya, serta perkembangan aspek-aspek lainnya. Perubahan struktur sosial yang lebih luas serta sangat krusial pada saat ini beberapa kyai bersikap kontra produktif karena keterlibatannya beberapa kyai yang terlalu jauh di dalam persoalan politik meskipun kalau kita tinjau ke belakang sejarah mencatat kontribusi perjuangan para kyai dari waktu ke waktu tidak pernah absen di dalam proses membangun bangsa ini.

Oleh karena itu K.H Abdul Alim telah mengantisipasi hal tersebut, beliau terus melakukan pembaharuan untuk meningkatkan kualitas kyai/ustadz guru dimana mereka mengajar. K.H. Abdul Alim mencoba melakukan perekrutan tenaga pengajar sebaik mungkin dengan kualifikasi yang sangat tinggi dengan menerapkan peraturan yang sangat ketat dimana tenaga pengajar minimal harus S1 dan diharapkan kebanyakan merupakan lulusan S-2. Dengan kualifikasi yang tinggi diharapkan adanya kualitas yang tinggi pula dalam menyampaikan materi yang sesuai dengan bidang keilmuannya. Pesantren memiliki peran vital dalam upayanya 1) transmisi dan transfer ilmuilmu keislaman, 2) menjaga tradisi, dan 3) reproduksi ulama. Selain ketiga peran tersebut, pesantren pun tumbuh dalam masyarakat untuk melayani berbagai 
kebutuhan mereka. Selaras dengan itu maka diperlukan kyai, tenaga pengajar yang berkualitas agar dapat mencapati tujuan adanya pesantren tersebut.

\section{SIMPULAN}

Dari kajian teori dan uraian hasil penelitian, maka diperoleh beberapa kesimpulan berdasarkan rumusan masalah yang ada sebagai berikut;

1. Perubahan visi dan misi.

2. Perubahan kurikulum; berasal dari lokal pondok, kemenag, kemendiknas, melakukan pembelajaran bahasa asing, dan ilmu komputer.

3. Perubahan isi/Subtansi; pembahasan ilmu agama dengan kurikulum gontor, bahasa Asing, pelajaran agama, materi umum, bahasa inggris dkk.

4. Perubahan metode pendidikan; terdapat sistem sekolah formal berjenjang, hafalan, musyawarah, ceramah, sistem modern, study banding, seminar, penggunaan media, hafalan, demonstrasi, ekperimen.

5. Perubahan sarana dan prasarana; modern, memiliki laboratorium, komputer, LCD.

6. Perubahan Kelembagaan; lembaga pondok dan sistem madrasah, jama'ah qiraatul qutub madrasah, gedung pembelajaran.

7. Perubahan tenaga pendidik; harus memiliki kualifikasi khusus dibidangnya, jika guru umum harus minimal S-1dan diutamakan S-2, jika mengajar ilmu agama harus merupakan lulusan pondok yang jelas dan memiliki syarat-syarat tertentu.

\section{DAFTAR PUSTAKA}

Ahmadi, R., 2014. Metodologi penelitian kualitatif. Yogyakarta: Ar-Ruzz Media.

Alamer, M., 2009. Effect of feeding fennel straw (Foeniculum vulgare Mill) on performance of lactating goats. J. Appl. Anim. Res. 36, 61-64.

AR, Z.T., 2018. Dinamika Perkembangan Kurikulum Pendidikan Pesantren; Satu Analisis Filosofis. El-Banat J. Pemikir. dan Pendidik. Islam 8, 1-21.

Azra, A., 2017. Surau: Pendidikan Islam Tradisi dalam Transisi dan Modernisasi. Kencana.

Badar, M., 2018. Kepemimpinan Kepala Madrasah dalam Pengembangan Madrasah Berprestasi: Studi Multikasus di Madrasah Aliyah Negeri 2 Kota Malang, Madrasah Aliyah Unggulan Amanatul Ummah Surabaya, dan Madrasah Aliyah Unggulan Darul Ulum Jombang. 
88 | Tarbawi : Jurnal Pendidikan Islam Vol. 17. No. 2. Juli - Desember 2020

Basyit, A., 2017. Pembaharuan Model Pesantren: Respon Terhadap Modernitas. Kordinat| J. Komun. Antar Perguru. Tinggi Agama Islam 16, 293-324.

Finch, E., 2012. Facilities change management. Wiley Online Library.

Fridiyanto, 2018. MANAJEMEN PERUBAHAN PERGURUAN TINGGI ISLAM: Studi Transformasi UIN SU dan UIN Ar-Raniry Banda Aceh. UIN Malang.

Hafidh, Z., 2017. Peran kepemimpinan kiai dalam peningkatan kualitas pondok pesantren di kabupaten ciamis.

Jamaluddin, M., 2012. Metamorfosis Pesantren Di Era Globalisasi. KARSA J. Soc. Islam. Cult. 20, 127-139.

Lubis, T., 2012. Peran kyai dalam pengembangan Pendidikan Agama Islam di Pesantren Lirboyo Kediri.

Masrur, A., 2014. Modernisasi pendidikan Islam: telaah pemikiran Azyumardi Azra tentang modernisasi pendidikan Islam di Indonesia.

Syamsudin, S., 2017. Sejarah dan Dinamika Lembaga-lembaga Pendidikan Islam di Nusantara (Surau, Meunasah, Pesantren dan Madrasah). Pendidik. Islam 1, 33-52. 